\title{
$\mathrm{pm}$ 胃癌の臨床病理学的検討
}

\author{
癌研究会付属病院外科 \\ 池田 孝明 堀 雅晴高木 国夫

\section{CLINICO-PATHOLOGICAL STUDIES ON THE INTRAMUSCULAR CANCER (PM) OF THE STOMACH}

\author{
Takaaki IKEDA, Masaharu HORI and Kunio TAKAGI
}

Surgical Department of Cancer Inttitute Hospital

癌研病院外科に括いて1946年より75年までに手術された $\mathrm{pm}$ 胃癌は452例である.肉眼形態で早期癌 類似 pm 胃癌と Borrman 型 pm 胃癌に大別し分析を試みた。 pm 胃癌の 5 年生存率は肉眼形態, リン 八節転移, 組織型で有意の差が認められた。早期癌類似 pm 胃癌は深達度 sm の早期胃癌と, Borrman 型 $\mathrm{pm}$ 胃癌は深達度 $\mathrm{ss}$ の進全癌と, 5 年生存率, リンパ節転移の頻度, 組織型の割合に扣いてきわめ て近い関係にあることが判明した。 また癌の pm への浸潤形式を scattered type と massive type に 2 大別してみると, 早期癌類似 pm 胃癌では scattered type の割合が多く, Borrman 型 pm 胃癌では massive type が多い.pmへの浸潤形式においても両者が異なる性格をもつものと考学られる.

索引用語：pm 胃癌

I.はじめに

近年胃癌に関しては診断学の進歩により早期胃癌の 頻度は増加し臨床病理学的に詳細な検討がなされてき た. それに比較し, pm 胃癌についてはいまだ十分な検 討が加えられていない現状である。

今回著者らは第41回胃癌研究会（1983年 7 月 2 日名 古屋市)において pm 胃癌が検討されたのを機会に, 当 院経験例に和ける pm 胃癌を臨床病理学的に検討し, 若干の知見を得たので報告する。

\section{II. 対象おぼび方法}

1946年より75年までの 30 年間に癌研外科にて切除し た pm 胃癌452例を対象とした．うちわけは，絶対治瘾 切除症例329例, 相対治瘜切除症例89例, 相対非治瘾切 除症例15例, 絶対非治瘾切除症例19例である。

肉眼形態で pm 胃癌を早期癌類似 pm 胃癌とBorrman 型 $\mathrm{pm}$ 胃癌に 2 大別したが，これは摘出標本なら びに組織所見により分類した。

\section{III. 結 果}

切除胃癌全体の中で pm 胃癌の頻度を年次的にみる と,わずかながら減少の傾向にあり 70 年代 $9.2 \%$ となっ

$<1984$ 年11月21日受理 $>$ 別刷請求先：池田 孝明 T170 豊島区上池袋 $1-37-1$ 癌研究会病院外科
ている，早期胃癌は著しく増加しているが，深達度 ss の胃癌は $\mathrm{pm}$ 胃癌上り減少の傾向が強い。深達度 $\mathrm{s}$ 以 上の胃癌はやや减少の傾向にあるが, 大きな变化はみ られていない(表 1).

絶対非治瘜切除19症例中, 肝転移症例は 8 例で, う ち 7 例が Borrman 2型であった。また肝転移 8 症例中 7 例が高分化型腺癌であった. 腹膜播種症例は 3 例で, 全例 Borrman 3で 3 例ともにリンパ節転移であった (表 2).

絶対非治痨切除症例を除いた $\mathrm{pm}$ 胃癌の平均年龄は 54.9 歳, 男女比は1.6：1であった. 腫瘍の最大径の平

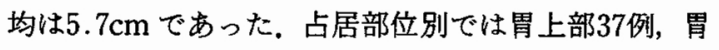
中部114例, 胃下部282例であった。

$\mathrm{pm}$ 胃癌の 5 年生存率は絶対治瘾切除症例 $82.1 \%$, 相対治癒切除症例 $50.6 \%$, 相対非治癒切除症例 $20.0 \%$, この 3 者をあわせた 5 年生存率は $73.4 \%$ あ゙あった。絶 対非治癒切除症例中リンパ節転移 $\mathrm{n}_{4}$ 症例 1 例のみが 5 年生存している(表 3 ).

腫湟の最大径別に 5 年生存率をみてみると $2 \mathrm{~cm}$ 末 満の 5 年生存率は $85.0 \%, 2 \mathrm{~cm}$ から $4 \mathrm{~cm}$ では $80.7 \%$, $4 \mathrm{~cm}$ から $6 \mathrm{~cm}$ のものでは $75.0 \% 6 \mathrm{~cm}$ 以上のものでは $64.6 \%$ と最大径が大きくなるにしたがい 5 年生存率は 低くなる傾向がみられた。占居部位別 5 年生存率では 
表 1 胃癌深達度別頻度の変遷（1946～75年）

\begin{tabular}{|c|c|c|c|c|c|}
\hline & m & sm & pm & ss & S以上 \\
\hline 1946～50年 & - & $0.5 \% \quad 1 / 201$ & $13.9 \% 2 \% / 201$ & $32.8 \% \quad 66 / 201$ & $52.8 \% \quad 106 / 201$ \\
\hline 1951～55年 & $0.9 \% 5 / 5 n$ & $3.3 \% \quad 19 / 572$ & $17.3 \% 9 / 572$ & $38.6 \% 221 / 52$ & $39.9 \% 228 / 572$ \\
\hline 1956〜60年 & $2.5 \% 20 / 60 \%$ & $5.8 \% 47 / 200$ & $11.2 \% \% / 006$ & $45.5 \% 367 / 806$ & $35.0 \% 282 / 606$ \\
\hline 1961～65年 & $8.9 \% \mathrm{~m} / \mathrm{m}$ & $10.3 \% \%$ & $7.9 \% 61 / m$ & $30.1 \% 233 / m^{4}$ & $42.8 \% \quad 31 / 734$ \\
\hline 1966～70年 & $15.1 \% 119 / 200$ & $13.7 \% 100 / 700$ & $9.9 \% \pi / 180$ & $17.4 \% \quad 137 / 709$ & $43.9 \% 307 / 700$ \\
\hline 1971～75年 & $19.9 \% 167 / 840$ & $18.5 \% 155 / 640$ & $9.2 \% \pi / 300$ & $10.0 \% \quad 81 / 840$ & $42.4 \% 357 / 840$ \\
\hline 1946～75年 & $9.5 \% 300 / 30$ & $10.3 \% 410 / 30 \%$ & $10.9 \%$ & $27.8 \% 100 / 390$ & $=41.5 \%$ \\
\hline
\end{tabular}

表 $2 \mathrm{pm}$ 胃癌, 絶対非治庱切除19症例

\begin{tabular}{|c|c|c|c|c|c|c|c|c|}
\hline & \multicolumn{3}{|c|}{ 肉既型 } & \multicolumn{2}{|c|}{ 粗 㤠 } & \multicolumn{2}{|c|}{ リンパ亩転移 } & 平均生存期成 \\
\hline 肝転移 & 8 例 & $\begin{array}{l}\text { Borr. II } \\
\text { Borr. V }\end{array}$ & $\begin{array}{l}7 \text { 侧 } \\
1 \text { 例 }\end{array}$ & $\begin{array}{l}\text { pap } \\
\text { tub } \\
\text { por }\end{array}$ & $\begin{array}{l}5 \text { 侸 } \\
2 \text { 例 } \\
1 \text { 例 }\end{array}$ & $\begin{array}{l}n_{1} \\
n_{2} \\
n_{3} \\
n_{4}\end{array}$ & $\begin{array}{l}1 \text { 例 } \\
3 \text { 例 } \\
1 \text { 例 } \\
3 \text { 例 }\end{array}$ & 10.5カ月 \\
\hline 腹缕搭種 & 3 例 & Borr.III & 3 例 & $\begin{array}{l}\text { tub } \\
\text { mn } \\
\text { por }\end{array}$ & $\begin{array}{l}1 \text { 例 } \\
1 \text { 例 } \\
1 \text { 时 }\end{array}$ & $\begin{array}{l}\mathrm{n}_{1} \\
\mathrm{n}_{2} \\
\mathrm{n}_{3}\end{array}$ & $\begin{array}{l}1 \text { 例 } \\
1 \text { 例 } \\
1 \text { 例 }\end{array}$ & 18.0カ月 \\
\hline リンバ简転移N、 & 8 例 & $\begin{array}{l}\text { Borr. Ill } \\
\text { Borr. II } \\
\text { 早期密類倒 }\end{array}$ & $\begin{array}{l}4 \text { 例 } \\
3 \text { 葡 }\end{array}$ & $\begin{array}{l}\text { pap } \\
\text { tub } \\
\text { por }\end{array}$ & $\begin{array}{l}3 \text { 喟 } \\
3 \text { 泡 } \\
2 \text { 例 }\end{array}$ & nu & 8 例 & 16.9 月 \\
\hline
\end{tabular}

表 $3 \mathrm{pm}$ 胃癌治撚切除別 5 年生存率

\begin{tabular}{|c|c|c|c|}
\hline 絶対治虑切除症例 & 329例 & 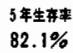 & $270 / 329$ \\
\hline 相対治窟切除症例 & 89例 & $50.6 \%$ & $45 / 89$ \\
\hline 相対非治虑切除症例 & 15例 & $20.0 \%$ & $3 / 15$ \\
\hline & 433例 & $73.4 \%$ & $318 / 433$ \\
\hline 色対非 & 19例 & $5.3 \%$ & $1 / 19$ \\
\hline
\end{tabular}

胃中部が78.9\%ともっとも良好であるが, 統計学的に は各部位に有意の差は認められなかった（表 4 ）。

リンパ節転移別に 5 年生存率を見てみると, $\mathrm{n}_{0}$

表 4 最大径 5 年生存率

\begin{tabular}{|c|c|c|}
\hline 大绳 & \multicolumn{2}{|c|}{5 年生本 } \\
\hline $2.0 \mathrm{~cm}$ 末 & $85.0 \%$ & $17 / 20$ \\
\hline $2.0 \sim 4.0 \mathrm{~cm}$ & $80.7 \%$ & $3 / 114$ \\
\hline $4.0 \sim 6.0 \mathrm{~cm}$ & $75.0 \%$ & $109 / 152$ \\
\hline $6.0 \mathrm{~cm}$ 以上 & $64.6 \%$ & $\$ / 1167$ \\
\hline
\end{tabular}

部位別 5 年生存率

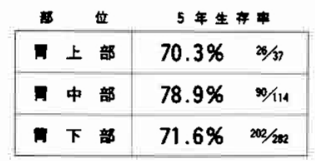

$87.4 \%, \mathrm{n}_{1} 75.4 \%, \mathrm{n}_{2} 48.9 \%, \mathrm{n}_{3} 23.1 \%$ あるる. $\mathrm{n}_{0}-\mathrm{n}$, 間, $\mathrm{n}_{1}-\mathrm{n}_{2}$ 間には有意の差が認められた（表 5 ).

$\mathrm{n}$, リンパ節転移陽性例の中で幽門下 ( 6 番)に転移の あった群と, それ以外の群にわけると胃下部では幽門 下転移陽性群の 5 年生存率は69.6\%と, 幽門下に転移 がなく, 小弯大弯にリンパ節転移のあった群より同じ $\mathrm{n}_{1}$ です 5 年生存率が低い傾向にあった（表 6).

\section{表 5 リンパ節転移別 5 年生存率}

\begin{tabular}{|c|c|}
\hline no $_{0}$ & $87.4 \% \quad 166 / 190$ \\
\hline$n_{1}$ & $75.4 \% \quad 104 / 138$ \\
\hline$n_{2}$ & $48.9 \% \quad 45 / 92$ \\
\hline$n_{3}$ & $23.1 \% \quad 3 / 13$ \\
\hline
\end{tabular}

表 $6 \mathrm{n}_{1}(+)$ 症例と 5 年生存率（胃下部）

\begin{tabular}{|c|c|c|c|}
\hline $\begin{array}{c}n(+) \\
\text { 为下 }(-)\end{array}$ & $\begin{array}{l}\text { 小孞 } \\
\text { 大弯 } \\
\text { 小弯・大弯 }\end{array}$ & $\begin{array}{ll}92.3 \% & 12 / 13 \\
87.5 \% & 14 / 16 \\
85.7 \% & 6 / 7\end{array}$ & $88.9 \% \quad 32 / 36$ \\
\hline $\begin{array}{c}n_{1}(+) \\
\text { 四門下 }(+)\end{array}$ & 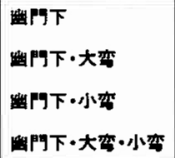 & $\begin{array}{ll}74.3 \% & 26 / 35 \\
69.2 \% & 9 / 13 \\
62.5 \% & 5 / 8 \\
61.5 \% & 8 / 13\end{array}$ & $69.6 \% \quad 48 / 69$ \\
\hline
\end{tabular}


また胃中部でも同様の傾向が認められた（表 7). 癌の周囲組織に対する浸潤増殖様式 INF $\alpha, \beta, \gamma$ 別で は, $\alpha$ の 年生存率は74.4\%, $\beta 71.1 \%, \gamma 75.9 \%$ で $\alpha, \beta, \gamma$ 間に有意の差は認められなかった（表 8 ）.

組織型別に 5 年生存率を見てみると pap $63.1 \%$ tub $71.2 \%$, por $79.2 \%$, muc $33.3 \%$, sig $94.4 \%$ となって 扣り pap一por間, por一muc間, muc一Sig 間には有 意の差が認められた。 また papでは $\mathrm{n}_{0}$ の 5 年生存率 $70.0 \%, \mathrm{n}_{1} 81.8 \%$ で, $\mathrm{n}_{1}$ より $\mathrm{n}_{0}$ 症例の 5 年生存率が低 い傾向にあった（表 9 ).

次に肉眼形態で早期癌類似 pm 胃癌とBorrman 型 $\mathrm{pm}$ 胃癌に 2 大別して 5 年生存率をみてみる. 早期癌 類似 $\mathrm{pm}$ 胃癌は77例で, 5 年生存率は90.9\%であった。 Borrman 型 pm 胃癌は356例で 5 年生存率は68.8\% で，両者の間には有意の差が認められた。また $\mathrm{n}_{0}$ のし める割合は早期癌類似 $\mathrm{pm}$ 胃癌で $64.9 \%$, Borrman 型 $\mathrm{pm}$ 胃癌 $39.3 \%$ と両者の間で有意の差が認められた (表10).

また pmへの癌の浸潤形式を scattered type と massive type に分けると, 早期癌類似 pm 胃癌では massive に pm へ浸潤するものは14.3\%, Borrman 型 $\mathrm{pm}$ 胃癌では60.1\%である。早期癌類似 pm 胃癌は

表 $7 \mathrm{n}_{1}(+)$ 症例之 5 年生存率（胃中部）

\begin{tabular}{|c|c|c|c|}
\hline $\begin{array}{c}n(+) \\
\text { 幽F下 }(-)\end{array}$ & $\begin{array}{l}\text { 小弯 } \\
\text { 大弯 } \\
\text { 小驾・大弯 }\end{array}$ & $\begin{array}{cc}76.9 \% & 10 / 13 \\
50.0 \% & 1 / 2 \\
100.0 \% & 2 / 2\end{array}$ & $76.5 \% \quad 13 / 17$ \\
\hline $\begin{array}{c}n_{1}(t) \\
\operatorname{PIT}(t)\end{array}$ & 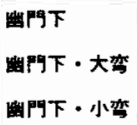 & $\begin{array}{rr}75.0 \% & 3 / 4 \\
50.0 \% & 1 / 2 \\
0 \% & 0 / 1\end{array}$ & $57.1 \% \quad 4 / 7$ \\
\hline
\end{tabular}

表 8 浸潤増殖様式と 5 年生存率

\begin{tabular}{|c|cc|}
\hline$\alpha$ & $74.4 \%$ & $67 / 90$ \\
\hline$\beta$ & $71.1 \%$ & $155 / 218$ \\
\hline$\gamma$ & $75.9 \%$ & $85 / 112$ \\
\hline
\end{tabular}

表 9 組䅱型別 5 年生存率

\begin{tabular}{|c|c|c|c|c|c|c|c|}
\hline & & & $n_{t}$ & & $n_{i}$ & $n_{z}$ & n: \\
\hline pap & $63.1 \%$ & $\Phi / 103$ & $70.0 \%$ & $\%$ & $81.8 \%$ ग & $37.0 \% \mathrm{~min}$ & $0 \% \%$ \\
\hline tub & $71.2 \%$ & $10 / 16$ & $88.9 \%$ & 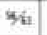 & $70.9 \%=$ & $43.8 \% \mathrm{w}$ & $33.3 \% \%$ \\
\hline por & $79.2 \%$ & $N_{10}$ & $94.6 \%$ & 94 & $74.4 \%=$ & $59.1 \% 13 / 2$ & $0 \% \%$ \\
\hline muc & $33.3 \%$ & 3 & $66.7 \%$ & 35 & $0 \%$ & $33.056 \mathrm{~h}$ & \\
\hline sig & $94,4 \%$ & 积 & $100.0 \%$ & $9 / 10$ & $100,0 \%$ & $66.7 \% 3$ & \\
\hline
\end{tabular}

表10 肉眼分類別・リンパ節転移別 5 年生存率

\begin{tabular}{|c|c|c|c|c|c|c|}
\hline 4 & & & $n_{0}$ & $n_{i}$ & $n_{i}$ & n: \\
\hline$I+I a$ & 1 & $100.0 \% 1 / 1$ & - & $100.0 \% \mathrm{~K}$ & - & - \\
\hline IC & 23 & $91.3 \% \pi / 23$ & $100.0 \% \mathrm{w} / 14$ & $100.0 \% 3$ & $0 \% \%$ & - \\
\hline $\mathbf{I} c+\mathbf{I} \mathbf{a}$ & 13 & $92.3 \% 13 / 13$ & $100.0 \% 3$ & $100.0 \% \quad 3 / 3$ & $66.7 \% 3 / 3$ & $\longrightarrow$ \\
\hline$I c+I b$ & 4 & $100.0 \% \%$ & $100.0 \% 3 / 3$ & $\ldots$ & $100.0 \%$ \% & - \\
\hline Ic + I & 36 & $88.9 \% 3 / 3$ & $96.2 \% \mathrm{x} / \mathrm{x}$ & $100.0 \% \%$ & $50.0 \% \quad 3 / 6$ & - \\
\hline 㝇 & 77 & $90.9 \% \mathrm{~m} / \mathrm{n}$ & $98.0 \% \% / 50$ & $100.0 \% \mathrm{r} / 1 \mathrm{~s}$ & $50.0 \% \quad 6 / 12$ & 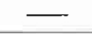 \\
\hline Borrman I & 6 & $50.0 \% 3 / 6$ & $66.7 \% \quad 2 / 3$ & $50.0 \% \quad 1 / 2$ & $0 \% \%$ & - \\
\hline Borrman I & 176 & $68.8 \% 121 / 1 \pi$ & $82.4 \% 61 / 44$ & $74.6 \% \mathrm{~m} / 50$ & $39.4 \% 13 / 33$ & $30.0 \% 3 / 10$ \\
\hline Borrman I & 153 & $71.9 \%=0 / 15$ & $84.9 \% \mathrm{~s} / 53$ & $72.7 \% \propto / 50$ & $59.5 \% \approx / 12$ & $0 \% \% / 3$ \\
\hline Borrman N & 7 & $71.4 \% 5 / 7$ & $80.0 \% \%$ & $0 \% \%$ & $100.0 \% \quad 1 / 1$ & 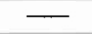 \\
\hline Borrman V & 14 & $64.3 \%$ \%/14 & $100.0 \% \quad 5 / 3$ & $66.7 \% \quad \%$ & $0 \% \%$ & - \\
\hline st & 356 & $69.7 \% 24 / 35$ & $83.6 \% 117 / 140$ & $72.4 \% \% / 123$ & $48.8 \% 3 / 10$ & $23.1 \% 3 / 13$ \\
\hline
\end{tabular}

scattered type が多く, Borrman 型 pm 胃癌は massive type が多く両者の間には pm の漫潤形式にお いても大きなちがいが認められた。早期癌類似 pm 胃 癌の中では IIc+IIa 類似の症例で massive type が多 く, Borrman 型 pm 胃癌の中では Borrman 2 型の症 例に massive type が多くなっている（表11）.

手術術式では, 胃上部27例中, 胃全摘脞尾側切除脾 摘術（胃摘 ps）14例，胃全摘術12例噴門側胃切除術 4 例，胃覀全摘術 7 例である. 噴門側胃切除術 4 例中, $\mathrm{n}_{0}$ 症例は 2 例, $\mathrm{n}_{1}$ 症例は 2 例で 5 年生存率は75\%で あった。

胃全摘術26例の 5 年生存率は $80.8 \%$, 胃摘 ps 26例の 5 年生存率は $42.3 \%$ である。胃全摘術のうち $\mathrm{n}_{0}$ 症例の 5 年生存率は $93.3 \%$, 胃摘 ps の 5 ち $\mathrm{n}_{0}$ 症例の 5 年生 存率は $81.8 \%$ で両者の間には統計的には有意の差は認 められないものの, 胃全摘術の方が 5 年生存率は高い 傾向がみられた。 $\mathrm{n}_{1}$ 症例, $\mathrm{n}_{2}$ 症例においてる胃全摘術の 方が, 胃摘 psより 5 年生存率が高い傾向がみられた

表11 pm への浸潤形式の頻度

\begin{tabular}{|c|c|c|}
\hline 问新 & Scattered type & massive type \\
\hline$I+\mathbb{I} a$ & 1 & 0 \\
\hline $\mathbf{1}_{\mathbf{c}}$ & 20 & 3 \\
\hline $\mathbf{I}_{c}+\mathbf{I}_{\mathbf{a}}$ & 7 & 6 \\
\hline$I_{c}+I_{b}$ & 4 & 0 \\
\hline $\mathbf{I}_{c}+\mathbf{I}$ & 34 & 2 \\
\hline yt & 66 & 11 \\
\hline Borrman I & 1 & 5 \\
\hline Borrman 1 & 55 & 121 \\
\hline Borrman & 73 & 80 \\
\hline BorrmanV & 7 & 0 \\
\hline BorrmanV & 6 & 8 \\
\hline st & 142 & 214 \\
\hline
\end{tabular}


表12 pm への漫潤形式と 5 年生存率

\begin{tabular}{|c|c|c|}
\hline 因 & scattesesd type & massive type \\
\hline$I+\mathbb{I} a$ & $100.0 \% 1 / 1$ & - \\
\hline Ic & $95.0 \% 1 \%$ & $66.7 \% \quad 2 / 3$ \\
\hline $\mathbb{I c}+$ Ia & $100.0 \% \mathrm{~T}$ & $83.3 \% 5 / 6$ \\
\hline $\mathbb{I} c+\mathbb{I b}$ & $100.0 \% \%$ & - \\
\hline Ic $+\mathbf{I}$ & $91.2 \% 31 / 34$ & $50.0 \% \quad 1 / 2$ \\
\hline of & $93.9 \% \approx 6 / 66$ & $72.7 \% \approx / 11$ \\
\hline Borrman I & $0 \% \%$ & $60.0 \% 3 / 5$ \\
\hline Borrman II & $83.6 \% * 5 / 55$ & $62.0 \% 75 / 121$ \\
\hline Borrman II & $75.3 \% 5 / 13$ & $68.8 \% 55 / 60$ \\
\hline BorrmanN & $71.4 \% 5 / 7$ & - \\
\hline BorrmanV & $50.0 \% \quad 3 / 6$ & $75.0 \% \%$ \\
\hline it & $76.8 \% 109 / 118$ & $65.0 \% 139 / 214$ \\
\hline
\end{tabular}

(表13).

$\mathrm{pm}$ 胃癌を深達度 $\mathrm{m}, \mathrm{sm}, \mathrm{ss}$ の胃癌と 5 年生存率, リ ンパ節転移の頻度, 組織型の割合をみてみる。

胃癌深達度別 5 年生存率では, 早期癌類似 $\mathrm{pm}$ 胃癌 は90.9\%で深達度 sm の早期癌の $91.0 \%$ ときわめて近 い值となっている. Borrman 型 pm 胃癌の 5 年生存率 は $69.7 \%$ と深達度 $\mathrm{sm}$ の早期癌と比較しかなり低い值 となっている(表14).

リンパ節転移の頻度では, 早期癌類似 $\mathrm{pm}$ 胃癌で, リ

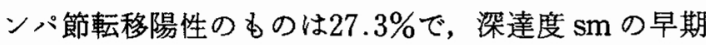
癌の $21.5 \%$ と近い値を示す. Borrman 型 pm 胃癌のり ンパ節転移陽性率は $60.8 \%$ で, 深達度 ss の進行癌の $68.1 \%$ と近い値を示している（表15）.

組織型で分化型と末分化型の割合は，早期癌の場合

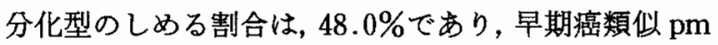

表13 術式別・占居部位別 5 年生存率

\begin{tabular}{|c|c|c|c|c|c|c|}
\hline & 切(再重全主) & & 再第P & & 切 & $P$ \\
\hline 而上新 & $85.7 \% \%$ & $91.7 \% 11 / 2$ & $42.9 \%$ & $8 / 14$ & $75.0 \% \quad 3 / 4$ & - \\
\hline 雨中部 & $90.4 \% \quad 2 / 3$ & $88.9 \%$ \% & $45.5 \%$ & $3 / 11$ & - & - \\
\hline 胃下部 & $72.3 \% \quad 196 / 2 n$ & $40.0 \% 3 / 5$ & $0 \%$ & $\%$ & - & $40.0 \%$ \\
\hline 鼓 & $77.2 \% \mathrm{~m} / \mathrm{mn}$ & $80.8 \% \mathrm{2} / \mathrm{s}$ & $42.3 \%$ & $11 / 36$ & $75.0 \% \quad 3 / 4$ & $40.0 \%$ \\
\hline
\end{tabular}

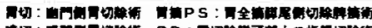

術式別リンパ節転移別 5 年生存率

\begin{tabular}{|c|c|c|c|c|c|c|c|}
\hline & $n_{0}$ & & $n_{1}$ & & $\mathrm{n}_{2}$ & & $n_{1}$ \\
\hline 成全演 & $93.3 \%$ & $19 / 15$ & $71.4 \%$ & $3 / 4$ & $50.0 \%$ & $3 / 4$ & - \\
\hline F描P & $81.8 \%$ & \% & $25.0 \%$ & $1 / 4$ & $9.1 \%$ & $1 / 11$ & 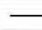 \\
\hline
\end{tabular}

表14 胃癌深達度と 5 年生存率（1946 75年）

\begin{tabular}{|c|c|c|c|c|}
\hline$m$ & sm & 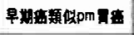 & Borrman型pm 露 & ss \\
\hline $93.9 \% \quad 357 / 380$ & $91.0 \% \quad 373 / 410$ & $90.9 \% \quad 70 / 77$ & $69.7 \% \quad 248 / 356$ & $52.5 \% \quad 582 / 1108$ \\
\hline
\end{tabular}

表15 リンパ節転移陽性の頻度（1946～75年）

\begin{tabular}{|c|c|c|c|c|}
\hline $\mathrm{m}$ & sm & 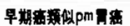 & Borrman型pm 贯 & ss \\
\hline $3.4 \% \quad 13 / 380$ & $21.5 \% 88 / 410$ & $27.3 \% \quad 21 / 77$ & $60.8 \% 216 / 35$ & $68.1 \% \quad 754 / 1108$ \\
\hline
\end{tabular}

表16 組織型の割合（1946～75年）

\begin{tabular}{|c|c|c|c|c|c|c|c|c|}
\hline & \multicolumn{2}{|c|}{$m, s m$} & \multicolumn{2}{|c|}{ 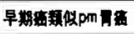 } & \multicolumn{2}{|c|}{ 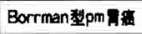 } & \multicolumn{2}{|c|}{ ss } \\
\hline 分化 型 & $48.0 \%$ & $379 / 790$ & $48.1 \%$ & $37 / 77$ & $67.6 \%$ & $223 / 330$ & $68.8 \%$ & $762 / 1108$ \\
\hline 末分化型 & $52.0 \%$ & $411 / 790$ & $51.9 \%$ & $40 / 77$ & $32.4 \%$ & $107 / 330$ & $31.2 \%$ & $346 / 1108$ \\
\hline
\end{tabular}

胃癌では分化型 $48.1 \%$ ときわめて近い値となってい る. Borrman 型 $\mathrm{pm}$ 胃癌では分化型のしめる割合は $67.6 \%$ と深達度 ss の進行癌の $68.8 \%$ と近い值を示し ている(表16).

\section{IV. 考 察}

$\mathrm{pm}$ 胃癌は早期癌上り進行癌への進展形式を解明す る上で，多くの解析が加兄られてきだて4).

$\mathrm{pm}$ 胃癌は 5 年生存率でみると, 深達度 ss 以上の進 行癌より早期癌に近いとい党る。リンパ節転移の頻度, 組織型の割合をみると進行癌に近いものともいえる。 このように pm 胃癌は早期癌と進行癌の両方の性格を そなえているとも言えるのである。広田らは ${ }^{5)} \mathrm{pm}$ 胃癌 は頻度の差こそあれ, 低悪性度のものと, 高悪性度の ものとが混在した 1 つの群であると述べている。佐 野6) とどまるすのと早期癌の段階から直ちにss拈よび $\mathrm{s}$ に浸潤を進める速度の速い癌があることを述べてい る. 表現の差こそあれ, pm 胃癌は性格の異なる 2 種類 以上の集合体と思われる，今回われわれは肉眼形態で $\mathrm{pm}$ 胃癌を早期癌類似 pm 胃癌と Borrman 型 pm 胃 癌の 2 つ大大別し, 分析を試みた. 早期癌類似 $\mathrm{pm}$ 胃癌 は深達度 sm の早期胃癌と, Borrman 型 pm 胃癌は, 深達度 ss と胃癌と, 5 年生存率, リンパ節転移の頻度, 組織型の割合に括いて，きわめて近い関係にある事が 判明した。早期癌より進行癌への時間的進展の解明は 困難であるが, $\mathrm{pm} へ$ 癌の浸潤形式をふけめ, 以後病 理学的に詳細な検討をまちたい。

次に $\mathrm{pm}$ 胃癌特有の問題としては, 血行転移の問題 があげられる. 山田ら7によると, 非癌死を除外した癌 死に対する肝転移の頻度は早期癌 $43.0 \%, \mathrm{pm}$ 胃癌 $25.9 \%$, So $16.7 \%$, s $9.6 \%$ と予後の上い浅在性のも のにかかって高くみられると報告している，当院では 肝転移再発は早期癌で $1.2 \%$, 癌死に対する割合は $54.5 \% \mathrm{pm}$ 胃癌では $4.4 \%$, 癌死に対する割合は $55.9 \%$ であった。このように肝転移再発の頻度は早癌の 3 倍 
以上であり, 特に高分化型腺癌 pap の場合 $7.8 \%$ にの ぼる。

山田らフによれば，肝転移はリンパ節転移に関係が 深く, リンパ節転移陽性群に肝転移が多く, 開腹時す でに肝転移を認めた症例にいたってはその $60 \%$ は $\mathrm{n}_{3}$ 以上のリンパ節転移が認められたと報告している。胃 壁の固有筇層の解剖学的特徵として, 毛細リンパ管抒 よび毛細血管の豊富な存在がある、肝転移の高頻度に みられる組䄽型 pap 症例の場合, 再発肝転移のみられ た 8 例中 4 例が $n_{0}$ 症例であった点を考えてみると，血 管への侵襲の方が早期に怙こるのではないかといら考 えも成り立つ。これは毛細リンパ管の密に分布してい るところは毛細血管の分布している層よりも深層であ る8)という解剖学的理由によるものか, あるいは高分 化型腺癌が血中へはいりこみやすい性質のためかは不 明であるが，いずれにしても $\mathrm{pm}$ 胃癌では $\mathrm{n}_{0}$ 症例より 肝転移再発を括こしらる事に十分注意すべきと思われ る. リンパ節転移と予後の関係では $\mathrm{n}_{0}-\mathrm{n}_{1}$ 間, $\mathrm{n}_{1}-\mathrm{n}_{2}$ 間に, 5 年生存率で有意の差が認められているが, $\mathrm{n}_{1}$ 群 の中でも幽門下 ( 6 番) に転移が認めた症例は他の $\mathrm{n}_{1}$ 群より 5 年生存率が低い傾向が浔められている. pm 胃癌の $\mathrm{n}_{3}$ 症例13例中幽門下に転移のあったものは12 例である。 うち 5 例は腸間膜根部に， 3 例は朠後部に 転移がみられている. 中島ら9゙よると, 一群リンパ節 と二群, 三群への定型的なリンパ流として幽門下部よ り膵後部・肝十二指腸靯帯を経由して腹腔動脈周囲へ 向らリンパ流と, 幽門下ょり腸間膜根部へ向らリンパ 流をあげているが，連関速度では，腸間膜根部へ向ら リンパ流の方が大きく，幽門下に転移のあった群の 5 年生存率が低い一つの理由になるのではないかと考觉 ている。

\section{V. 結 論}

1. $\mathrm{pm}$ 胃癌を肉眼形態で, 早期癌類似 $\mathrm{pm}$ 胃癌々 Borrman 型 $\mathrm{pm}$ 胃癌とに分類すると, 早期癌類似 $\mathrm{pm}$ 胃癌は, 深達度 sm の早期癌と, Borrman 型 $\mathrm{pm}$ 胃癌 は, 深達度 ss の進行胃癌と 5 年生存率, リンバ節転移 の頻度, 組織型の割合に打いて, きわめて近い関係に ある。
2. 癌の pm への浸潤形式を scattered type と massive type に2 大別してみると, 早期癌類似 $\mathrm{pm}$ 胃癌で は scattered type の割合が多く, Borrman 型 pm 胃癌 では massive type の割合が多く, pmへの浸潤形式に おいても両者が異なる性格をるつものと考えられる。

3. 早期癌類似 pm 胃癌の 5 年生存率は $90.9 \%$, Bor$\mathrm{rman}$ 型 $\mathrm{pm}$ 胃癌の 5 年生存率は $68.8 \%$ で両者の間に は有意の差が認められた。

4. 組織型別 5 年生存率は sig $94.4 \%$, por $79.2 \%$, pap $63.1 \%$, muc 33.3\%であり, 組織型別に有意の差 が認められた。

5.リンパ節転移別 5 年生存率は $\mathrm{n}_{0} 87.4 \% \mathrm{n}_{1}$ $75.4 \%, \mathrm{n}_{2} 48.9 \%$ であり, $\mathrm{n}_{0}-\mathrm{n}_{1}$ 間, $\mathrm{n}_{1}-\mathrm{n}_{2}$ 間に有意 の差が認められた。

6. 胃下部，胃中部において， $\mathrm{n}_{1}$ 群の 5 年生存率に掠 いて幽門下にリンパ節転移のあるもの之, 小弯・大弯 のみに転移のあるすのを比較すると，幽門下に転移の ある群の方が，低い傾向がみられた。

\section{文 献}

1）紀藤 毅, 今 永一, 山田栄吉注か: 固有筋層 (Pm) にとどまる胃癌の予後。手術 $26: 281$ $-286,1972$

2）紀藤 毅, 今 永一, 山田栄吉注か：pm 胃癌の病 態生理. 癌の臨 $22: 15-20,1976$

3）村上忠重, 安井 昭, 中山 旭活か：早期胃癌の概 念と未期胃癌とのむすびつき，日臨 25:1322 $-1327,1967$

4）北岡久三：病理組織学的にみた早期胃癌から進行 癌せの進展, 胃々腸 $5: 15-23,1970$

5）広田映五, 下田忠和, 佐野量造：pm 胃癌の病理 一早期胃癌と進行胃癌の関連性一. 胃々腸 11 ： $827-845,1976$

6）佐野量造：胃疾患の臨床病理. 東京, 医学書院, $1974, \mathrm{p} 112$

7) 山田栄吉, 宮石成一, 黒柳弥寿雄活か：胃癌の肝転 移. 外科 $36: 349-357,1973$

8）木原卓三郎：リンパ管系の解剖。脈管学 6 ： $15-18,1966$

9）中島聰總，高橋知之，高木国夫：胃癌のリンバ節転 移パターンと予後。日消外会誌 $16: 1184,1983$ 